DOI: https://doi.org/10.47405/mjssh.v6i8.976

\begin{tabular}{|c|c|}
\hline 4 & Malaysian Journal of Social Sciences and Humanities (MJSSH) \\
\hline $\begin{array}{l}\text { Malaysian Juoural of } \\
\text { Social ccciecces and }\end{array}$ & Volume 6, Issue 8, August 2021 \\
\hline (MJ-sSH) & e-ISSN : 2504-8562 \\
\hline & $\begin{array}{l}\text { Journal home page: } \\
\text { www.msocialsciences.com }\end{array}$ \\
\hline
\end{tabular}

\title{
Faktor Pembentukan Kejeleketan dalam Pengendalian Sesi Kaunseling Kelompok
}

\author{
Abdul Rashid Abdul Aziz¹, Mohd Zaliridzal Zakaria1, Nor Hamizah Ab Razak ${ }^{1}$ \\ ${ }^{1}$ Fakulti Kepimpinan dan Pengurusan, Universiti Sains Islam Malaysia (USIM) \\ Correspondence: Abdul Rashid Abdul Aziz (rashid@usim.edu.my)
}

\begin{abstract}
Abstrak
Kaunseling kelompok merupakan satu bentuk perhubungan menolong yang memerlukan interaksi antara ahli kelompok. Terdapat elemen yang perlu dipupuk dalam kalangan ahli kelompok bagi memastikan matlamat yang ditetapkan boleh dicapai. Kejeleketan adalah merupakan pencapaian kesepaduan yang erat dalam kalangan individu yang seterusnya dapat menghasilkan nilai kekitaan. Pembentukan perasaan ini sesama ahli kelompok adalah satu keperluan penting dalam memastikan pelaksanaan kaunseling kelompok berkesan. Oleh itu, kajian ini adalah bertujuan untuk mengkaji faktor-faktor yang mempengaruhi pembentukan kejeleketan dalam sesi kaunseling kelompok. Kajian ini menggunakan kaedah kajian kualitatif menerusi analisis kandungan terhadap jurnal-jurnal berindeks tinggi seperti Scopus, Social Sciences Citation Index (SSCI) dan Science Direct. Analisis yang telah dijalankan menjelaskan antara faktor penyumbang kepada terbentuknya kejeleketan dalam sesi kaunseling kelompok adalah interaksi, penerimaan ahli, kebersamaan, saiz kelompok, perkongsian rasa, konflik dan sikap. Justeru, faktor-faktor ini perlu diberi perhatian secara jitu oleh kaunselor dalam mengendalikan sesi kaunseling kelompok dengan berkesan.
\end{abstract}

Kata Kunci: kejeleketan, kaunseling, kaunseling kelompok

\section{Contributing Factors of Cohesiveness Formation in Conducting Group Counseling Session}

\begin{abstract}
Group counseling is a form of helping relationships that requires interaction between group members. There are elements that need to be emphasized among group members to ensure that the set goals can be achieved. Cohesiveness is the achievement of close coherence among individuals in group which in turn can produce the sense of belonging. The formation of these feelings among group members is an important requirement in ensuring the effective implementation of group counseling. Therefore, this study aimed to examine the factors influencing the formation of cohesiveness in group counseling sessions. This study uses qualitative research methods through content analysis of high index journals such as Scopus, Social Sciences Citation Index (SSCI) and Science Direct.The analysis that has been conducted explains that among the factors contributing to the formation of cohesiveness in group counseling sessions are interaction, member acceptance, togetherness, group size, sharing of feelings, conflict and attitude. Therefore, these factors need to be given close attention by counselors in conducting group counseling sessions effectively.
\end{abstract}

Keywords: Cohesiveness, counseling, group counseling 


\section{Pengenalan}

Kaunseling kelompok ialah satu pendekatan yang boleh digunakan oleh kaunselor terlatih untuk menyediakan satu perhubungan menolong yang berkesan kepada beberapa orang individu biasa yang sedang berhadapan dengan isu-isu seharian yang normal dalam satu jangka masa yang sama (Zuraidah, 2004). Umumnya, dalam kaunseling kelompok, ahli cuba menangani masalah yang mereka hadapi dengan bantuan ahli-ahli lain yang mungkin menghadapi situasi yang hampir sama (Ida Hartina, 2006). Pembentukan kelompok perlu disediakan secara rasional dan rapi serta selari dengan jenis kelompok yang akan diselenggarakan (Othman, 2005). Hal ini bagi memastikan perjalanan kelompok berjalan lancar mengikut perancangan yang disediakan.

Kaunseling kelompok secara mudah dapat difahami menerusi definisi yang diberikan oleh Gladding (2015) iaitu ia adalah satu sesi berkumpulan yang melibatkan dua atau lebih individu yang bertemu secara langsung atau secara interaktif, saling bergantung peranan, dengan kesedaran bahawa masingmasing tergolong dalam satu kumpulan bagi mencapai tujuan yang dipersetujui bersama . Manakala Association for Specialists in Group Work (2000) pula mendefinisikan kaunseling kelompok sebagai satu amalan profesional yang luas yang melibatkan penerapan pengetahuan dan kemahiran dalam proses menolong berkelompok untuk membantu satu kumpulan individu yang saling bergantung untuk mencapai tujuan bersama mereka, yang mungkin berkaitan dengan isu-isu intrapersonal, interpersonal, atau pekerjaan. Matlamat kaunseling kelompok boleh merangkumi pelaksanaan tugas yang berkaitan dengan pekerjaan, pendidikan, pengembangan diri, penyelesaian masalah peribadi dan interpersonal, atau pemulihan gangguan mental dan emosi.

Hal ini menunjukkan bahawa, kaunseling kelompok merupakan satu wadah perhubungan menolong yang berfungsi dalam proses pembangunan dan perkembangan individu melalui interaksi yang wujud di dalam kelompok itu sendiri. Suasana dan interaksi awal yang tercipta ini seperti yang dinyatakan oleh Zuraidah (2005), sebagai 'group feeling' atau perasaan kelompok yang kelihatan dalam kalangan ahli. Perasaan mesra perlu disemai seawal mungkin bagi memastikan pembentukan semangat kekitaan dalam kalangan ahli kelompok berjalan lancar ke peringkat yang seterusnya dalam kelompok. Usaha memupuk dan membina kejeleketan sebenarnya amat sesuai diaplikasikan dalam sesi kaunseling, terutamanya kaunseling kelompok, kerana kaunseling itu sendiri menurut Feltham (1995) dan Strong, (2005), dapat dinyatakan sebagai usaha untuk memahami 'nilai bersama' selain dari memberi atau menerima nasihat.

Istilah kejeleketan khususnya di dalam kelompok memperlihatkan satu pencapaian kesepaduan yang erat dalam kalangan individu yang dapat menghasilkan nilai kekitaan atau sense of belonging di antara ahli. Kewujudan elemen ini sangat penting sebagai nadi ke arah menggerakkan proses kelompok mencapai matlamat yang telah ditetapkan. Hal ini kerana, tanpa nilai perpaduan dan kekitaan yang tinggi, mustahil ahli kelompok dapat menjana sikap prihatin dan mengambil berat di antara satu sama lain. Ini ditekankan oleh Zuraidah (2004), iaitu kejeleketan yang terbina di dalam kelompok menunjukkan bahawa kelompok itu telah berjaya membina perasaan bersepadu yang teguh dalam kalangan ahlinya. Justeru, kesepaduan yang telah berjaya diwujudkan ini akan mendorong kedatangan ahli secara lebih menggalakkan dan mereka akan berasa bimbang mengenai kebajikan diri ahli jika seseorang ahli kelompok itu tidak menghadiri sesi yang dijalankan (Yalom \& Leszcz, 2005).

Menurut Zuraidah (2004) lagi, kejeleketan dapat dilihat wujud secara jitu dalam sesebuah kelompok apabila ahli-ahli telah berasa selesa di antara satu sama lain. Selain itu, mereka juga dilihat telah mula menaruh kepercayaan dan hormat menghormati. Tambahnya lagi, menerusi wujudnya perasaan ini, ia seterusnya akan menggalakkan ahli untuk berkongsi perasaan dan pengalaman serta mampu menceritakan kisah-kisah peribadi yang terpendam seperti sebab-sebab sebenar mereka menjadi ahli kelompok, rahsia-rahsia seks yang mereka sembunyikan dan perasaan terpendam yang lain akan turut diceritakan tanpa ragu-ragu (Zuraidah, 2004). Ogrodniczuk dan Piper (2003) serta Yalom dan Leszcz, (2005) dalam Marmarosh et al. (2005) pernah berteori bahawa kejeleketan kelompok dapat memberikan dorongan kepada ahli kelompok untuk berusaha untuk "menjadi lebih baik" atau dengan 
harapan yang optimis untuk penambahbaikan perkembangan harga diri. Oleh itu, ahli dari kumpulan yang jeleket dapat mengambil bahagian dalam terapi dan kaunseling kelompok dan mempunyai harapan yang lebih besar bahawa terapi dan kaunseling kelompok akan membantu mereka mencapai hasil yang diinginkan untuk diri sendiri.

Ironinya, kejeleketan ini sebenarnya juga adalah berkait rapat dengan aspek yang merangkumi kehidupan semasa yang dilalui sama ada secara sedar atau tidak. Dalam kehidupan seharian, proses membina kejeleketan ini sebenarnya berlaku dalam pelbagai lapangan interaksi sosial seperti di sekolah, pejabat, tapak pembinaan, organisasi atau berpersatuan, serta juga boleh meliputi kejeleketan yang berlaku di dalam sektor ketenteraan (Hogg, 1992, 1993; Gladding, 2015). Kejeleketan amnya, merupakan satu proses membina hubungan akrab, menjalinkan silaturahim atau persahabatan dan kekeluargaan.

Sebagai faktor terakhir dalam proses menormalkan hubungan interpersonal dalam sesi kaunseling kelompok, kejeleketan telah mendapat banyak perhatian. Ia diakui secara meluas sebagai faktor penting kejayaan sesuatu kelompok kaunseling (Yalom \& Leszcz, 2005; Marmarosh et al., 2005; Burlingame et al., 2011). Kejeleketan kelompok dan individu dapat diukur dengan tingkah laku, seperti kehadiran, ketepatan waktu, pengambilan risiko, pendedahan diri, dan kadar putus sekolah. Kejeleketan kelompok lebih berkesan dalam corak komunikasi mereka, dan ahli sering berkomunikasi antara satu sama lain. Kelompok yang telah membina kejeleketan akan kelihatan senang bersama namun masih menumpukan fokus yang berorientasikan pencapaian, terutama pada tugasan dan tanggungjawab yang sukar. Mereka dapat menyatakan permusuhan dan konflik mereka secara terbuka dan mendapat beberapa ketetapan seterusnya membina persefahaman antara satu sama lain (Forsyth \& Diederich, 2014).

Walau bagaimanapun, kejeleketan ada kalanya boleh mewujudkan masalah. Antara kesukaran yang berpotensi wujud dengan kejeleketan ahli kelompok ialah apabila ahli kelompok memutuskan bahawa mereka hanya menyukai suasana positif sehingga mereka tidak mahu membicarakan apa-apa yang mungkin menjengkelkan atau boleh mewujudkan situasi negatif dalam kelompok. Dalam sesi kelompok seperti itu, keharmonian kelompok lebih ditekankan melebihi segalanya, dan ia mewujudkan satu bentuk penerimaan pseudo (penerimaan palsu) dalam kelompok. Suasana seperti ini dapat mengelakkan kebimbangan, tetapi ini menjadikan kelompok sukar untuk berkembang dan terus maju (Gladding, 2015).

\section{Sorotan Literatur}

\section{Memahami Kejeleketan}

Kejeleketan secara umumnya dilihat berbeza-beza antara satu kelompok dengan kelompok yang lain, berdasarkan kepada nilai serta semangat kekitaan dalam kelompok yang terbentuk (Yalom \& Leszcz, 2005). Secara umum, kejeleketan adalah satu rasa kesepaduan dan keterikatan dengan kelompok, sedangkan iklim kelompok adalah persepsi keseluruhan terhadap persekitaran kumpulan (Marmarosh \& Amy, 2020).

Istilah kejeleketan (cohesiveness) merupakan istilah pinjaman yang digunakan oleh pakar kaunseling kelompok dari disiplin ilmu psikologi sosial dan penyelidik dinamika kumpulan. Konsep kejeleketan kelompok ini berpusat pada mekanisme atau kekuatan yang menyatukan ahli kelompok yang menjadikan mereka tetap terhubung dengan kelompok melalui satu ikatan dalam perhubungan menolong yang terbina. Pakar kaunseling kelompok menggambarkannya sebagai pengalaman keterhubungan, dinyatakan sebagai kekitaan atau "we-ness", atau sebagai sebahagian daripada keseluruhan. Dalam pengertian ini, kejeleketan adalah kekuatan kolaboratif, yang disusun melalui dedikasi bersama untuk mencapai tujuan bersama oleh kelompok. Pakar kaunseling kelompok juga menekankan kepentingan hubungan antara ahli kelompok dan tarikan ahli kelompok terhadap kelompok dan pemimpinnya. Ikatan ini mewujudkan sistem hubungan yang kemudiannya membentuk struktur dalam menyusun dari mana kejeleketan akan bermula. Ini menggambarkan konsep kejeleketan paling umum dan lazim digunakan dalam penyelidikan dan amalan kaunseling kelompok hari ini, iaitu 
sebagai komponen utama hubungan terapeutik dalam proses kaunseling dan psikoterapi kelompok (Marmarosh \& Amy, 2020). Secara tuntasnya, kejeleketan akan membangunkan rasa perpaduan, kekitaan, dan keselamatan dalam kelompok, kendatipun pada masa yang sama tekanan dan konflik sedang bergerak dalam kelompok.

Yalom dan Leszcz (2005) juga mendefinisikan kejeleketan kelompok sebagai satu hubungan yang bukan sahaja terbentuk antara ahli-ahli dengan kelompok, tetapi ianya merangkumi hubungan di antara sesama ahli dengan kelompok secara keseluruhannya. Napier dan Gershenfeld (2004) pula menyatakan bahawa kejeleketan kelompok adalah satu tahap yang terbentuk apabila seseorang ahli mendapati bahawa menerusi kelompok tersebut, telah terbina keperluan mereka serta mampu bekerjasama dan setia bersama kelompok bagi mencapai tujuan tertentu. Sementara itu, Festinger dan Thibaut, 1951 (di dalam Napier \& Gershenfeld, 2004) berpandangan bahawa kejeleketan kelompok ialah pembinaan semangat kekitaan yang tinggi, menerima dan selesa terhadap norma-norma kelompok serta pada masa yang sama, menerima kehadiran setiap ahli di dalam kelompok tersebut. Ini dinyatakan oleh Yalom, 1985 dan Gladding, 1995 (di dalam Napier \& Gershenfeld, 2004) yang mempersetujui bahawa semangat kekitaan merupakan satu petunjuk kepada pembinaan tahap kejeleketan yang baik dalam pembinaan kelompok. Ini kerana, menerusi pembinaan semangat dan nilai kekitaan tersebut, sekaligus meningkatkan keutuhan semangat ahli kelompok untuk mempertahankan kelompok tersebut dari sebarang gangguan sama ada dari dalam atau luar yang mampu merosakkan integriti perkelompokan tersebut. Semangat kekitaan sepertimana yang disebutkan oleh Yalom dan Leszcz (2005), sebagai 'weness' dapat dilihat menerusi sikap positif yang ditunjukkan oleh ahli melalui tindakan untuk hadir secara sukarela dalam sesi kelompok. Selain itu, tahap kejeleketan yang baik dapat dilihat menerusi elemen penyertaan, saling membantu, serta mempertahankan nilai-nilai kelompok di kalangan ahli (Gladding, 2015).

\section{Dimensi Kejeleketan}

Matlamat pembinaan kejeleketan di dalam kelompok sebenarnya bersandar kepada usaha untuk mewujudkan satu kekuatan atau arus tenaga yang mampu membawa ahli-ahli dalam sesebuah kelompok untuk bertambah akrab dan mengekalkan keakraban tersebut secara berterusan. Selain itu juga, kejeleketan ini dapat dilihat dalam dua dimensi pembentukan yang merangkumi kejeleketan bersifat emosi atau peribadi dan pembentukan kejeleketan yang bersifat penyelesaian sesuatu tugasan.

Kejeleketan bersandarkan emosi atau peribadi, adalah terbina menerusi perhubungan yang saling dirasai oleh setiap individu atau ahli di dalam kelompok yang terbentuk. Inilah yang sering diketengahkan oleh ilmuwan terdahulu bahawa setiap ahli kumpulan akan merasakan semangat kekitaan yang tinggi. Perasaan tersebut akan terbina apabila seseorang ahli merasakan dirinya sebagai sebahagian dari kelompok serta merasakan Burn, 2004; bahawa kelompok itu penting bagi dirinya (Yalom, 2005; Zuraidah , 2005; Amla, Zuria dan Salleh, 2006).

Dimensi kejeleketan dalam kelompok juga terbentuk apabila wujud sesuatu keperluan menyelesaikan tugasan. Untuk itu, secara nyata, kewujudan kejeleketan jenis ini dapat dikategorikan sebagai kejeleketan berorientasikan tugasan. Bagi mengukur tahap kejeleketan bagi kelompok berorientasikan tugasan, ianya dapat dilihat menerusi hasrat yang dikongsi bersama oleh ahli untuk menyelesaikan matlamat tugasan dan yang paling utama, individu-individu yang terlibat mampu untuk bersama-sama mencapai matlamat yang ditetapkan. Bagi memahami dimensi kejeleketan ini, Napier dan Gershenfeld (2004), menyatakan pandangan mereka bahawa dimensi kejeleketan berorientasikan tugasan ini dapat dilihat dalam persekitaran kerja, iaitu apabila kejeleketan mampu terbina dengan baik, maka tugasan tersebut juga akan dapat disempurnakan dengan kualiti yang tinggi melalui hasil kerjasama antara ahli.

\section{Peringkat Pembentukan Kejeleketan}

Pembinaan kejeleketan bukanlah semudah yang disangka, dan ianya bukanlah sesuatu perkara yang boleh dirancang. Kejeleketan secara jelasnya adalah satu penerimaan seseorang terhadap seseorang atau kelompok yang berkaitan dengan perihal hati dan perasaan. 
Bagi membina kejeleketan, sebenarnya ia perlu melalui beberapa tahap tertentu. Justeru itu, ramai sarjana di dalam bidang psikologi dan kaunseling telah mengemukakan pandangan mereka, di antaranya Kolk (1985), Corey (2012), Napier dan Gershenfeld (2004) serta Gladding (2015). Menurut Kolk (1985), pemeringkatan bagi membina kumpulan yang dinamik perlulah melalui empat tahap serta ianya memaparkan bahawa tahap kejeleketan adalah di tahap ketiga melepasi fasa permulaan dan konflik. Berikut adalah pemeringkatan yang dinyatakan oleh Kolk (1985) tersebut;
i. Peringkat permulaan dan pembinaan
ii. Peringkat konflik dan dominasi
iii. Peringkat kejeleketan dan produktif
iv. Peringkat penamatan

Menurut Kolk (1985), kejeleketan berlaku pada tahap ketiga di dalam kelompok. Ini disokong oleh Gladding, (2015), Capuzzi, Gross dan Stauffer (2006) serta Yalom dan Leszcz (2005), yang menyatakan tahap ketiga iaitu peringkat penyumbangan atau bekerja (produktif dan kejeleketan) sebagai pembentukan kejeleketan ahli kelompok sekali gus ini menunjukkan bahawa bagi membina kejeleketan di dalam kaunseling yang dijalankan, ianya perlu melalui satu proses yang memerlukan ketabahan serta kesabaran yang jitu di kalangan ahli. Ini kerana, sebelum berada di tahap kejeleketan, ahli perlu mengharungi proses kenal mengenali atau suai kenal serta juga perlu menghadapi konflik dan pertentangan sebelum sesuatu kejeleketan itu terbina dan memasuki fasa ketiga sesi kelompok. Ini disokong oleh Tuckman (1965) di dalam Burn (2004), menyatakan bahawa kejeleketan mula terhasil di peringkat 'norming' iaitu selepas melalui dua peringkat awal dalam kelompok iaitu 'forming' dan 'storming'. Peringkat 'norming' merupakan peringkat pembinaan situasi harmoni di kalangan ahli kelompok selepas melalui peringkat 'storming' atau pergolakan dan konflik.

Apabila sesuatu kelompok telah terbina keyakinan serta juga dilihat telah mencapai tahap kejeleketan, maka peringkat ini akan memudahkan para ahli kelompok untuk berani mengeluarkan pendapat tanpa rasa tergugat atau terancam, walaupun apa yang diperkatakan itu berbentuk peribadi (Amla, Zuria \& Salleh, 2006). Menerusi pembentukan kejeleketan juga, dapat meningkatkan kemampuan seseorang untuk mendedahkan aspek diri yang berkaitan dengan perihal peribadi. Tindakan ini dapat dilakukan kerana pembentukan serta kewujudan perasaan selamat yang didorong oleh tahap kejeleketan yang kukuh di kalangan ahli.

Kejeleketan sebenarnya mampu terbentuk apabila ahli di dalam kelompok telah mampu untuk memahami diri masing-masing serta dengan pemahaman dan penerimaan hakikat diri tersebut, ianya membolehkan penerokaan diri di dalam sesi kelompok berjaya dilakukan. Menerusi penerimaan hakikat diri, sekali gus ianya akan dapat meningkatkan perasaan penerimaan diri (self-acceptance) dan juga meningkatkan perasaan harga diri atau feeling of personal worth (Amla, Zuria \& Salleh, 2006). Wilson (1999) pula menyatakan bahawa terdapat lima tahap yang menentukan kejeleketan iaitu, persamaan tingkah laku, kejayaan kumpulan, memahami cara untuk mencapai matlamat, gaya pengurusan konflik serta berlakunya peneguhan positif yang kerap. Bagi mencapai tahap kejeleketan yang tinggi, Wilson (1999) juga menyatakan bahawa perlu wujud kepuasan dalam diri setiap ahli sesuatu kumpulan tersebut untuk memastikan ianya berjaya. Sekiranya ini gagal tercapai, maka semakin sukar sesebuah kumpulan tersebut untuk membina tahap kesempurnaan kejeleketannya.

\section{Metod Kajian}

Kajian ini menggunakan kaedah kajian kualitatif menerusi analisis kandungan terhadap artikel-artikel yang telah diterbitkan dalam pangkalan data seperti Scopus, Social Sciences Citation Index (SSCI) dan Science Direct. Ketiga-tiga enjin carian ini digunakan kerana mempunyai banyak artikel yang berindeks tinggi. Carian data digunakan dengan memfokuskan kepada beberapa kata kunci seperti 'kejeleketan' dan 'kaunseling kelompok'. Ciri-ciri bagi inclusion dan exclusion juga dimasukkan untuk memastikan artikel yang dipilih menepati jangka masa, kualiti dan sesuai untuk kajian. Proses screening dan eligibility juga turut digunakan dalam kajian ini untuk mendapatkan artikel yang menepati dengan kehendak, skop serta tujuan kajian. Maklumat artikel-artikel yang diperoleh 
dikumpulkan dan disaring serta dianalisis menggunakan teknik analisis kandungan. Analisis kandungan terhasil apabila pengkaji mempunyai matlamat untuk menjalankan kajian literatur pengkaji. Justeru, daripada analisis yang dijalankan, pengkaji dapat mengenal pasti faktor yang menyumbang kepada pembentukan kejeleketan dalam mengendalikan sesi kaunseling kelompok.

\section{Dapatan Kajian dan Perbincangan}

\section{Faktor-Faktor Pembentukan Kejeleketan}

Terdapat beberapa faktor yang mempengaruhi proses pembinaan kejeleketan. Sebagaimana yang telah diakui oleh Kolk (1985), Corey dan Corey (1987), Capuzzi, Gross dan Stauffer (2006) serta Gladding (2015), proses membina kejeleketan seharusnya berlaku pada awal peringkat sesi kaunseling dijalankan. Menerusi pemahaman terhadap faktor-faktor pembentukan kejeleketan dapat membolehkan para kaunselor serta ahli kelompok memainkan peranan masing-masing dengan berkesan. Oleh itu, faktor-faktor yang dapat mempengaruhi dan membina kejeleketan perlulah difahami dan diamati dengan baik dalam menghasilkan sebuah kelompok yang dinamik dan juga kondusif. Terdapat beberapa faktor yang dilihat mampu mempengaruhi kepada terbinanya kejeleketan iaitu:-

\section{Interaksi dalam kalangan ahli kelompok}

Secara umumnya, interaksi positif sama ada interaksi verbal atau fizikal mampu merangsang pembentukan kejeleketan. Apabila interaksi positif ini terbina, secara tidak langsung perasaan kejeleketan akan dapat dirasai oleh ahli kelompok. Bertepatan dengan pandangan yang dikemukakan oleh Hogg (1992, 1993), Wilson (1999) serta Gladding (2015) yang menegaskan bahawa aspek interaksi memainkan peranan penting di dalam membina kejeleketan. Selain itu, tempoh terbentuknya kejeleketan dalam sesebuah kelompok juga dipengaruhi oleh sejauh mana interaksi positif yang terbina di dalam kelompok tersebut.

Menurut Gladding (2015), di antara ciri-ciri kelompok yang jeleket dapat dilihat melalui keupayaan setiap ahli di dalam kelompok tersebut untuk saling berinteraksi dan berkomunikasi dengan berkesan. Oleh yang demikian, dapat dijelaskan bahawa pembentukan kejeleketan dapat dihasilkan melalui komunikasi dan pergaulan mesra sesama ahli. Maka dalam usaha mewujudkan kelompok yang jeleket dan dinamik, interaksi positif di antara ahli kelompok perlu terlebih dahulu dibentuk.

\section{Penerimaan sesama ahli}

Perasaan diterima atau dialu-alukan oleh ahli kelompok mampu meningkatkan pembentukan kejeleketan dalam sesebuah kelompok. Penerimaan sesama ahli kelompok ini merupakan antara prasyarat penting dalam membentuk kejeleketan. Menerusi perasaan penerimaan ini secara tidak langsung dapat meningkatkan perasaan kekitaan yang seterusnya mencetuskan perasaan-perasaan positif lain seperti bertolak ansur, saling mengenali dan membina hubungan mesra. Selain itu, penerimaan sesama ahli turut menimbulkan perasan tarikan terhadap kelompok dan juga perasan saling berhubung di antara ahli kelompok yang lain (Mohd Mansur \& Nordinar, 1996). Dalam erti kata lain, dengan terbinanya perasaan penerimaan sesama ahli, ia akan menyediakan satu daya penarik di dalam kelompok. Perkara ini bertepatan dengan fungsi kejeleketan seperti yang dinyatakan Yalom (1985) (di dalam Kline, 2003) bahawa kejeleketan adalah 'daya penarik yang dipunyai ahli terhadap kumpulannya serta juga terhadap ahli kumpulan yang lain’.

Penerimaan oleh ahli di dalam kelompok juga dapat digambarkan sebagai sebuah kepercayaan. Menerusi kewujudan kepercayaan dalam diri setiap ahli terhadap ahli lain akan merangsang lagi penerimaan sesama ahli di dalam kelompok. Bersesuaian dengan pandangan Sue dan Sue (2003) (di dalam Capuzzi, Gross \& Stauffer, 2006), yang menyatakan bahawa kepercayaan adalah satu unsur penting bagi mewujudkan kejeleketan di dalam kelompok. Selain itu, Deutsch, 1959 \& 1967 (di dalam Mohd Mansur dan Nordinar (1996) turut menjelaskan bahawa sesebuah kelompok yang mendapat 
sokongan ahli lebih menarik minat ahli untuk membina hubungan berbanding dengan kelompok yang sering bercanggah dan berkonflik. Justeru, bagi membolehkan sesi kelompok mencapai tahap kedinamikan yang berkesan, elemen penerimaan perlu segera terbina. Menerusi kewujudan konsep penerimaan di kalangan ahli kelompok, maka secara jelasnya membawa kepada pembentukan kejeleketan. Perkara ini disokong oleh Hogg (1992), Yalom (1985) serta Napier dan Gershenfeld (2004), Norriss dan Niebuhr serta Corey et al. (1988) yang turut memperincikan lagi bahawa faktor penerimaan sesama ahli ini sebagai asas untuk kelompok membina norma-norma bersama dengan mewujudkan sifat mengambil berat sesama ahli.

Di samping itu, dapat dikaitkan juga elemen silaturahim yang ditegaskan dalam agama Islam merupakan paparan kepada sikap saling menerima secara terbuka tanpa bersikap prejudis dan saling mempercayai sesama ahli kelompok. Jika sikap silaturahim ini mampu dibentuk di dalam kelompok, maka sekali gus ia sebenarnya telah membantu dalam pembinaan kejeleketan ke arah melahirkan kelompok yang dinamik. Justeru itu, penerimaan sesama ahli perlu wujud bagi memastikan perasaan kekitaan dapat terbentuk seterusnya menghasilkan kelompok yang dinamik dan kondusif.

\section{Kebersamaan}

Faktor-faktor kebersamaan seperti agama, pekerjaan, bangsa dan tahap sosial ekonomi juga dilihat sebagai salah satu di antara faktor yang mampu memberikan kesan di dalam pembentukan kejeleketan. Latar belakang seseorang ahli kelompok dengan ahli lain di dalam kelompok dilihat sebagai penyumbang kepada proses membina kejeleketan. Semakin banyak persamaan, maka semakin cepat kejeleketan akan dapat dibina. Ini bertepatan dengan saranan Hogg $(1992,1993)$ (di dalam Posthuma, 1996) yang menyatakan bahawa kejeleketan dipengaruhi oleh sifat kebersamaan serta penglibatan ahli di dalam kelompok.

Kebersamaan dari segi corak personaliti dan tingkah laku juga turut menyumbang kepada proses membina kejeleketan. Ini kerana menerusi tingkah laku ahli kelompok yang mudah mesra, mampu berinteraksi dengan baik serta bersikap menolong akan menjadikan proses membina kejeleketan dapat dipercepatkan. Theodorson (1957) (di dalam Hogg, 1992), menyatakan bahawa terdapat perkaitan hubungan yang positif di antara nilai-nilai sesama ahli kelompok dengan tahap kejeleketan.

Selain itu, kebersamaan kedudukan atau status juga mempengaruhi dan menentukan kejeleketan dalam kelompok. Menurut Hogg (1993), faktor demografi yang merangkumi kedudukan dan status sosial berperanan dalam proses membina kejeleketan. Ini dapat dilihat apabila sesebuah kelompok yang dibahagikan mengikut jenis pekerjaan, bidang profesional serta kedudukan sosial akan mudah jelekit dan membolehkan kejeleketan mudah terbina jika dibandingkan dengan kelompok yang mempunyai percampuran status.

Menerusi faktor ini, dapat dirumuskan bahawa semakin besar persamaan di antara ahli-ahli kelompok, maka semakin mudah untuk membina kejeleketan. Perkara ini adalah selari dengan teori identiti sosial yang menyatakan bahawa manusia akan lebih dekat dengan manusia yang mempunyai ciri-ciri yang sama dengan mereka, sama ada persamaan itu dalam bentuk luaran iaitu dari segi kaum atau bangsa serta agama, dan juga berbentuk dalaman seperti nilai diri seseorang.

\section{Saiz kelompok}

Wilson (2014) menjelaskan bahawa saiz kelompok berkait rapat dengan proses evolusi atau perkembangan sesuatu kelompok. Semakin kecil sesebuah kelompok, maka semakin mudah koordinasi dan kerjasama dapat dibina. Dalam erti kata lain, saiz kelompok yang kecil memudahkan kesepakatan dalam kelompok dapat dicapai terutamanya dalam membuat sesuatu keputusan. Kebanyakan pengkaji lepas seperti Wilson, (2014), Mohd Mansur dan Siti Nordinar (1996) juga berpendapat bahawa kelompok kecil selalunya lebih jeleket berbanding dengan kelompok besar.

Di samping itu, saiz kelompok juga mempengaruhi tingkah laku dan norma kelompok dari segi penglibatan menyeluruh ahli di dalam kelompok, aspek kepimpinan, tindak balas ahli, serta keupayaan 
ahli untuk mencapai persefahaman dan persetujuan terhadap sesuatu perkara (Wilson, 1999). Sekiranya tempoh yang lama diambil oleh ahli kelompok untuk mencapai persefahaman akan mempengaruhi proses sesebuah kelompok untuk maju dari satu peringkat ke peringkat yang lain. Sebagaimana yang dinyatakan oleh Capuzzi et al. (2010), Corey (2012) serta Gladding (2015) persefahaman diperlukan bagi mencapai tahap kejeleketan dan mendorong penamatan. Justeru itu, saiz kelompok semestilah ideal dan juga dibina berdasarkan sesuatu matlamat dan juga demografi tertentu.

\section{Berkongsi persaingan, ancaman luaran dan kekecewaan}

Berkongsi perasaan dalam persaingan secara bersama dan saling merasakan wujudnya ancaman terhadap kelompok dilihat membantu dalam pembentukan kelompok yang lebih berkejeleketan tinggi (Hogg, 1992). Ini kerana, setiap ahli akan lebih bekerjasama dan mencari persamaan di antara satu sama lain serta menolak sebarang pertelingkahan dalam berhadapan dengan cabaran yang perlu dilalui untuk mengatasi pihak lawan. Kesedaran setiap ahli kelompok terhadap ancaman yang perlu ditempuhi bersama menyebabkan ahli kelompok sentiasa bersama-sama berkongsi matlamat dan sekali gus merapatkan kerjasama sesama ahli. Melalui kerjasama yang terbentuk ini, ia seterusnya menggalakkan kejeleketan berlaku (Hogg, 1993).

Ada kalanya persaingan atau ancaman terhadap kelompok membawa kepada kekecewaan ahli kelompok. Oleh itu, kekecewaan yang dihadapi oleh ahli atau kelompok juga mampu mendorong kepada kejeleketan walaupun ianya hanya sebagai faktor minimum. Namun begitu, Hogg (1992) tetap menyatakan bahawa faktor tersebut merupakan sebagai sebahagian daripada elemen yang dapat menjana kejeleketan. Ini kerana, melalui wujudnya perasaan kecewa dan rasa terancam, terutamanya membabitkan pihak di luar dari kelompok telah mendorong kelompok tersebut untuk bersama-sama mencari jalan mengharunginya. Justeru, ia sekali gus akan merangsang kelompok tersebut bersamasama berusaha mencari penyelesaian.

\section{Konflik}

Tidak dapat dinafikan kewujudan konflik sebenarnya boleh merangsang kepada pembentukan kejeleketan. Walaupun konflik sering dilihat sebagai unsur negatif dan mampu menyebabkan situasi tegang, namun sekiranya sesebuah kelompok itu mampu menerima dan mengadaptasi serta meraikan perbezaan secara tidak langsung dapat menghasilkan impak yang berkesan dalam membentuk kejeleketan. Ini kerana, sekiranya sesebuah kelompok mampu menerima dan berupaya mengurus konflik yang timbul dengan baik sebenarnya menggambarkan bahawa ahli kelompok dapat menguruskan kehadiran perasaan negatif dan juga perasaan positif dengan berkesan (Wilson, 2014).

Di samping itu, menerusi perbezaan dan konflik yang wujud juga secara tidak langsung sebenarnya mendidik hati dan perasaan setiap ahli untuk mengawal diri serta tetap memelihara semangat setia kawan untuk terus memupuk keharmonian dalam kelompok. Perkara ini turut menjelaskan bahawa sesebuah kelompok yang mampu menerima konflik dan dalam masa yang sama mengekalkan kejeleketan, adalah satu kelompok yang lebih dinamik berbanding kelompok-kelompok yang terlalu mudah bersikap positif namun mengetepikan realiti kehidupan. Dapat disimpulkan bahawa pemahaman terhadap nilai-nilai positif dan juga negatif di kalangan ahli-ahli mampu membawa ke arah persefahaman sesama ahli kelompok dan memangkinkan kejeleketan yang lebih akrab dan unggul.

\section{Bersikap mendiamkan diri}

Umumnya, kejeleketan sering kali dikaitkan dengan semangat kekitaan dan kebersamaan bagi mencapai sesuatu matlamat. Namun, kejeleketan sesebuah kelompok juga boleh dikenal pasti apabila ahli-ahli di dalam kelompok bersikap mendiamkan diri atau mengelakkan diri dari meluahkan perasaan ragu-ragu atau tidak puas hati terhadap kelompok. Back (1951) (di dalam Pruitt dan Lewis, 1977) menjelaskan tindakan ini bertujuan untuk membendung daripada timbulnya ketegangan di antara ahli kelompok. Ia sekali gus menyebabkan kelompok tersebut stabil dan juga mampu untuk mempercepatkan proses membina kejeleketan. Tindakan mendiamkan diri ini adalah baik di peringkat awal membina kejeleketan kelompok. Jika semua ahli bertindak secara terbuka meluahkan setiap 
ketidakpuasan hatinya terhadap ahli kelompok yang lain, maka, kelompok tersebut tidak akan mampu bergerak mencapai tahap kejeleketan seperti yang diharapkan.

Dalam konteks budaya Barat, nilai keterbukaan dan bebas menyatakan pandangan menjadi perkara biasa dan dianggap normal. Manakala, bagi perspektif pengamalan masyarakat Timur pula adalah berbeza. Meluahkan rasa hati secara terlalu terbuka tanpa menghiraukan perasaan ahli kelompok yang lain dianggap sebagai mementingkan diri oleh masyarakat Timur. Justeru, manifestasi tindakan bersikap mendiamkan diri ini menggambarkan bahawa sikap mementingkan kepentingan diri telah berjaya diketepikan demi mewujudkan satu norma kelompok yang harmoni. Bertepatan dengan saranan yang dikemukakan oleh Nadiyah (2005) bahawa nilai mementingkan diri sendiri melebihi daripada kelompok adalah berlawanan dengan budaya tertentu terutamanya bagi masyarakat Timur dan Asia.

Konklusinya, faktor-faktor yang telah dibincangkan adalah pemangkin kepada pembentukan kejeleketan dalam kelompok. Namun demikian, masih terdapat pelbagai lagi faktor-faktor yang mungkin wujud dan perlu dikaji. Faktor-faktor yang dibincangkan ini sangat penting untuk diberi perhatian oleh para kaunselor dan juga ahli kelompok. Ianya dapat memberi pendedahan kepada para kaunselor dan juga ahli kelompok untuk saling bekerjasama dalam membina kejeleketan. Tanpa terbinanya kejeleketan, pastinya tidak akan wujud penyertaan yang luhur dari kalangan ahli kelompok sebaliknya akan mewujudkan provokasi dan kekecewaan.

\section{Kesimpulan}

Kejeleketan merupakan suatu asas perhubungan di antara seseorang manusia dengan manusia lainnya. Ianya bukan sahaja bersifat aplikasi di sesuatu persekitaran sahaja, umpamanya pada sesi kaunseling kelompok semata-mata. Namun, aplikasi kejeleketan ini sebenarnya berfungsi jauh merangkumi aspek kehidupan semasa. Menerusi pengamatan terhadap kehidupan semasa inilah, maka terbinanya satu konsep iaitu kejeleketan untuk turut sama dimasukkan sebagai sebahagian kaedah bagi membolehkan sesuatu kaunseling kelompok dapat dijayakan.

Menyedari bahawa manusia itu adalah bersifat sosial atau berhubung di antara satu sama, maka sesuailah kejeleketan ini dipraktikkan dalam kaunseling kelompok. Ia juga bersesuaian dengan pemahaman kejeleketan yang membawa makna secara umum sebagai perhubungan sesama individu dalam sesuatu kelompok. Membina kejeleketan juga bererti membina silaturahim, dan dengan terbinanya silaturahim, maka ia akan memudahkan persefahaman serta penyelesaian kepada sesuatu permasalahan yang timbul. Melihat kepada signifikannya elemen kejeleketan dalam kaunseling kelompok turut menjelaskan bahawa para kaunselor perlu lah memperkasakan kemahiran-kemahiran kaunseling dalam merangsang pembentukan perasaan kejeleketan sesama ahli selain daripada memberi perhatian kepada faktor-faktor pembentukan kejeleketan yang telah dibincangkan. Justeru, memahami kejeleketan dan faktor-faktor yang menjadi pemangkin kepada kejeleketan adalah penting bagi memastikan tahap pemeringkatan dalam sesi kaunseling dapat berlaku dengan berkesan dan baik.

\section{Rujukan}

Amla, S., Zuria, M., dan Salleh, A. (2006). Bimbingan dan kaunseling sekolah, Bangi: Penerbit Universiti Kebangsaan Malaysia.

Association for specialists in group work professional standards for the training of group workers. (2000). The Journal for Specialists in Group Work, 25(4), 327-342. https://doi.org/10.1080/01933920008411677

Bayne, R., Horton, Ian., Merry, T., dan Noyes, E. (1994). The counsellor's handbook: a Practical A-Z guide to professional and clinal practice, London: Chapman \& Hall.

Beal, D. J., Cohen, R., Burke, M. J. \& McLendon, C. L. (2003). Cohesion and performance in groups: A meta-analytic clarification of construct relation. Journal of Applied Psychology, 88, 989-1004. 
menerusi Cohesiveness, Wikipedia, http://en.wikipedia.org/wiki/Cohesiveness, capaian pada 1 Julai 2021

Burlingame, G. M., McClendon, D. T., \& Alonso, J. (2011). Cohesion in Group Therapy. Psychotherapy, 48(1), 34-42. https://doi.org/10.1037/a0022063

Burn, S. M. (2004). Group: theory and practice, Canada: Thomson Wadsworth.

Capuzzi, D., Gross, D. R., \& Stauffer, M. D. (2010). Group Work (5th ed.). Love Publishing Company. Capuzzi, D., Gross, D.R., dan Stauffer M. D. (2006), Introduction to Group Work (4th ed.), Sydney: Love Publishing Company.

Corey, G. (2012). Theory and Practice of Counseling and Psychotherapy (9th ed.). Cengage Learning. Corey, G. (2015). Theory \& Practice of Group Counseling.

Corey, G., Corey. M.S., Callanan, P.J., Russell, J.M. (1988), Group Techniques. California: Brooks/ Cole Publishing Company.

Eisenberg, J. (2007). Group Cohesiveness, dalam R. F. Baumeister \& K. D. Vohs (Eds.), Encyclopaedia of Social Psychology, 386-388. Thousand Oaks, CA: Sage, menerusi Cohesiveness, Wikipedia, http://en.wikipedia.org/wiki/Cohesiveness, capaian pada 1 Julai 2021

Feltham, C. (1995). What is counseling? The promise and problem of the talking Therapies, New Delhi: Sage Publications.

Forsyth, D. R., \& Diederich, L. T. (2014). Group dynamics and development. In Handbook of group counseling and psychotherapy, 2nd ed. (pp. 34-45). Sage Publications, Inc. https://doi.org/10.4135/9781544308555.n3

Fullmer, D. W. (1978). Counseling: group theory and system (2 ed.), United States of America: Carroll Press.

Gladding, S. T. (1995). Group work: a counseling specialty (2 ed.), New Jersey: Merrill Prentice Hall.

Gladding, S. T. (2015). Groups : a Counseling Specialty (7th ed.). Pearson Education Inc.

Hogg, M. A. (1992). The social psychology of group cohesiveness: from attraction to social identity, New York: New York University Press.

Hogg, M. A. (1993). Group Cohesiveness: A Critical Review and Some New Directions. European Review of Social Psychology, 4(1), 85-111. https://doi.org/10.1080/14792779343000031

Ida Hartina, A. T. (2006). Memimpin kaunseling kelompok, Kuala Lumpur:PTS Professional.

Kline, W. B., (2003). Interactive group counseling and therapy, New Jersey: Marmarosh, C. L., \& Amy, S. (2020). Group Cohesion. In P. Craig D. \& T. Giorgio A. (Eds.), The Psychology of Groups: The Intersection of Social Psychology and Psychotherapy Research (p. 272). https://doi.org/10.1177/104649648001100401

Marmarosh, C., Holtz, A., \& Schottenbauer, M. (2005). Group cohesiveness, group-derived collective self-esteem, group-derived hope, and the well-being of group therapy members. Group Dynamics, 9(1), 32-44. https://doi.org/10.1037/1089-2699.9.1.32

Mohd Mansur A. dan Siti Nordinar M. T. (1996). Kaunseling kelompok, Skudai: Penerbit Universiti Teknologi Malaysia.

Nadiyah, E. (2005). Barat ke Timur: pembentukan kerangka teoretikal peribadi bagi kaunselor dan pekerja sosial Malaysia. Di dalam Azlin Hilma Hillaluddin, Fatimah Zailly Ahmad Ramli, Rusimah Sayuti dan Yusmarhaini Yusof, Isu-isu dan pendidikan kerja sosial. Sintok: Penerbit Universiti Utara Malaysia.

Napier, R. W., \& Gershenfeld, M. K. (2004). Groups: Theory and Experience (7th ed.). Houghton Mifflin.

Napier, R. W., dan Gershenfeld, M.K. (1989). Groups: theory and experience (4th ed.), New Jersey: Houghton Mifflin Company.

Othman, M. (2005). Prinsip psikoterapi dan pengurusan dalam kaunseling, Serdang: Penerbit Universiti Putra Malaysia.

Piper, W., Marrache, M., Lacroix, R., Richardson, A. \& Jones, B. (1983). Cohesion as a basic bond in groups. Human Relations, 36, 93-108, menerusi Cohesiveness, Wikipedia, http://en.wikipedia.org/wiki/Cohesiveness, capaian pada 1 Julai 2021

Posthuma, B.W. (1996). Small groups in counseling and therapy: process and leadership, Boston: Ally and Bacon.

Pruitt, D. G., dan Lewis, S. A. (1977). The psychology of integrative bargaining di dalam Druckman, Daniel (Eds). Negotiations, London: Sage Publications. 
DOI: https://doi.org/10.47405/mjssh.v6i8.976

Ridley, M. What Makes You Who You Are, di dalam Duffy, K. G. (2006). Personal Growth and Behaviour, Amerika Syarikat: McGraw Hill.

Strong, T. (2005). Understanding in counselling: A preliminary social constructionist and conversation analytic examination. British Journal of Guidance and Counselling, 33(4), 513-533.

Wilson, G. L. (2014). Groups in Context: Leadership and Participation in Small Groups (7th ed.). McGraw-Hill.

Wilson, G.L. (1999). Group in context: leadership and participation in small groups (5th ed.), Boston: McGraw-Hill College.

Yalom, I. D. (1985). The theory and practice og group psychotherapy (4th ed.), United States of America, Basic Books.

Yalom, I. D., \& Leszcz, M. (2005). Theory and Practice of Group Psychotherapy, Fifth Edition (5th ed.). Basic Books. http://www.amazon.com/dp/B001C310YY

Zuraidah A.R. (2004). Pengenalan kaunseling kelompok, Kuala Lumpur: IBS Buku Sdn Bhd. 